\title{
Linking valve closure behavior and sodium transport mechanism in freshwater clam Corbicula fluminea in response to copper
}

\author{
Chung-Min Liao ${ }^{\text {a,* }}$, Chieh-Ming Lin ${ }^{\text {a }}$, Li-John Jou ${ }^{\text {a,b }}$, Kuo-Chin Chiang a \\ ${ }^{a}$ Department of Bioenvironmental Systems Engineering, National Taiwan University, 1, Sec. 4, Roosevelt Road, Taipei, Taiwan 10617, ROC \\ ${ }^{\mathrm{b}}$ Department of Biomechatronic Engineering, National Ilan University, Ilan, Taiwan 260, ROC
}

Received 11 July 2006; received in revised form 6 September 2006; accepted 15 September 2006

A new flux-biological response model can link valve closure and sodium transport mechanisms in freshwater clam in response to copper.

\begin{abstract}
The purpose of this study is to develop a mechanistic model to describe a conceptually new "flux-biological response" approach based on biotic ligand model (BLM) and Michaelis-Menten (M-M) kinetics to allow the linkage between valve closure behavior and sodium (Na) transport mechanism in freshwater clam Corbicula fluminea in response to waterborne copper $(\mathrm{Cu})$. We test the proposed model against published data regarding Na uptake kinetics in rainbow trout and $\mathrm{Na}$ uptake profile in $C$. fluminea, confirming that the predictive model is robust. Here, we show that the predicted $\mathrm{M}-\mathrm{M}$ maximum $\mathrm{Cu}$ internalization flux in $C$. fluminea is $0.369 \mu \mathrm{mol} \mathrm{g}^{-1} \mathrm{~h}^{-1}$ with a half-saturation affinity constant of $7.87 \times 10^{-3} \mu \mathrm{M}$. Dynamics of Na uptake and valve closure daily rhythm driven by external Cu can also be predicted simultaneously. We suggest that this "Na transport-valve closure behavior" approach might provide the basis of a future design of biomonitoring tool.
\end{abstract}

(c) 2006 Elsevier Ltd. All rights reserved.

Keywords: Clam; Corbicula fluminea; Biotic ligand model; Valve closure behavior; Sodium transport; Copper

\section{Introduction}

Freshwater Corbicula fluminea is a commercially important native species and has a high market value to Taiwan's aquaculture (http://www.fa.gov.tw) with wide farming distribution in the western and eastern coastal areas of Taiwan. Yet, human activities have greatly increased the flux of many potential toxic metals to aquatic ecosystems. Therefore, if waterborne metals are elevated, pollutant-induced changes in the mobility can occur, which has potential risks on the health of clam, resulting in severe economic losses nation-wide due to bans on harvesting of contaminated clam and the need for costly monitoring programmes.

\footnotetext{
* Corresponding author. Tel.: +88622363 4512; fax: +886223626433.

E-mail address: cmliao@ntu.edu.tw (C.-M. Liao).
}

The development and implementation of effective remedial measures depend on our ability to predict the fate and effects of metals in these systems. The free ion activity model (FIAM) based on sound physicochemical and biological principles has shown great potential as predictive tools (Campbell, 1995; Morel and Hering, 1993; Hare and Tessier, 1996). FIAM suggests that the free ion concentration (or activity) plays a central role as a regulator of interactions (uptake, toxicity) between metals and aquatic organisms, postulating that only a small proportion of trace metals are found as free hydrated ions with the majority of the metal being complexed by ligands. Brown and Markich (2000) and Markich et al. (2003) have employed the extended FIAM to develop a conceptual model to quantify the effect of toxicity of $\mathrm{Cd}$ and $\mathrm{Cu}$ on valve movement behavior of freshwater bivalve Hyridella depressa. Markich et al. (2003) indicated that the valve movement behavior of $H$. depressa exposed to total $\mathrm{Cd}$ was directly proportional to 
the activity of the free metal ion $\left(\mathrm{Cd}^{2+}\right)$ in the linear region of the concentration-response profiles, indicating that the predictive acute toxicity to $H$. depressa supports the extended FIAM.

The biotic ligand model (BLM) is one of the new generation of models that describe the bioavailable fraction of metal causing toxicity in aquatic organisms (Paquin et al., 2002a,b; Niyogi and Wood, 2004). BLM quantifies the affinity and capacity of the gills (biotic ligand, BL) of aquatic organisms to bind metals and relates this binding to acute toxicity. BLM evolves from the gill surface interaction model (GSIM) (Pagenkopf, 1983) and the free ion activity model (FIAM) (Campbell, 1995). BLM linking with equilibrium geochemical modeling framework (i.e., Windermere humic aqueous mode (WHAM) (Tipping, 1994)) can describe the competition of the free metal ion with other naturally occurring cations (e.g., $\mathrm{Ca}^{2+}, \mathrm{Na}^{+}, \mathrm{Mg}^{2+}, \mathrm{H}^{+}$), together with complexation by abiotic ligands (e.g., DOM, chloride, carbonates, sulfide) for binding with the BL. The concentration of this metal-BL complex determines the magnitude of the toxic effect, independent of the physiochemical characteristics of the medium. Acute $\mathrm{Cu}$ toxicity is always associated with inhibition of sites involved in active $\mathrm{Na}^{+}$uptake at the gills, resulting in death from failure of $\mathrm{NaCl}$ homeostasis (Paquin et al., 2002a,b). This indicates that naturally occurring cations (e.g., $\mathrm{Na}^{+}$) can offer protection by competing with $\mathrm{Cu}^{2+}$ for binding sites on the gill, whereas naturally occurring anions can bind $\mathrm{Cu}^{2+}$, rendering it poorly available to gill sites.

One of the key problems of environmental toxicology remains how to best relate metal exposures to their biological effects. Most research has been based upon the assumption that equilibrium is attained between the metal in the bulk solution and that adsorbed to sensitive sites on the cell surface, i.e., metal internalization flux is rate-limiting. In such case, the metal-induced biological response can be related either to the free metal ion concentration in solution (basis of the FIAM), or to the metal bound to sensitive sites at the surface of the organism (basis of the BLM). Under such steady-state conditions, the metal internalization flux should follow a Michaelis-Menten (M-M) kinetic model (Paquin et al., 2002a,b; Chen and Liao, 2004; van Leeuwen et al., 2005). Our preliminary studies (Liao et al., submitted for publication) indicated that free ionic form of waterborne $\mathrm{Cu}$ bind specifically to a biotic ligand (i.e., clam gills) and impair normal valve closure behavior, indicating that a fixed-level of metal accumulation at a biotic ligand is required to elicit specific biological effects. Liao et al. (submitted for publication) also demonstrated that the time-dependent $\operatorname{EC50}(t)$ and valve closure behavior in response to $\mathrm{Cu}$ at any response time could be well predicted (Fig. 1A). Our preliminary results confirmed that BLM could be improved to analytically and rigorously describe the bioavailable fraction of metal causing toxicity to valve closure behavior in freshwater $C$. fluminea.

Bianchini et al. (2002) and Morgan and Wood (2004) indicated that acute metal toxicity is a function of $\mathrm{Na}^{+}$uptake rate, implying that $\mathrm{Na}^{+}$uptake data can be utilized to identify species sensitive to metal exposure and predict response time of biological behavior. Grosell et al. (2002) suggested that $\mathrm{Na}^{+}$ transport mechanism could be incorporated into BLM for risk management decisions. McCorkle and Dietz (1980) have examined the $\mathrm{Na}^{+}$transport mechanism in pondwater-acclimated $C$. fluminea, indicating that $\mathrm{Na}$ influx in $0.5 \mathrm{mM}$ $\mathrm{Na}_{2} \mathrm{SO}_{4}$ was estimated to be $7.90 \pm 0.79 \mu \mathrm{mol} \mathrm{Nag}{ }^{-1}$ dry tissue $\mathrm{h}^{-1}$. Saturation of the transport system followed the M-M kinetics, demonstrating that maximum influx $\left(J_{\max }\right)$ was $12.90 \pm 3.01 \mu \mathrm{mol} \mathrm{Nag} \mathrm{g}^{-1}$ dry tissue $\mathrm{h}^{-1}$ with a $\mathrm{M}-\mathrm{M}$ affinity constant $K_{\mathrm{m}}$ of $0.05 \mathrm{mM} \mathrm{Na}$ representing the Na concentration at which the influx equals $J_{\max } / 2$ (Fig. 1B). They also indicated that $\mathrm{Na}$ movement in $C$. fluminea may be classified into passive diffusion, excretion, exchange diffusion, and active transport in which exchange diffusion comprises a substantial portion $(67 \%)$ of $\mathrm{Na}$ movement of $5.91 \pm$ $0.80 \mu$ mol $\mathrm{Na} \mathrm{g}^{-1}$ dry tissue $\mathrm{h}^{-1}$.

However, knowing that the $\mathrm{Na}^{+}$turnover is a physiological process associated with the gill membranes and the key mechanism of acute metal toxicity consists of reduction in $\mathrm{Na}^{+}$ uptake by blockade of gill $\mathrm{Na}^{+} / \mathrm{K}^{+}$-ATPase in the gill of freshwater mussels (Saintsing and Towle, 1978; Dietz and Findley, 1980) and fish (Bianchini et al., 2002; Grosell et al., 2002; Paquin et al., 2002a,b; Morgan and Wood, 2004; Zhou et al., 2005), and recognizing that many of the factors that influence the valve closure behavior and $\mathrm{Na}^{+}$transport mechanism would normally operate on endogenous and dietary substances, we decided to propose a hypothesis (Fig. 1C).

The aim of this paper is to test the hypotheses that FIAM and BLM associated with $\mathrm{M}-\mathrm{M}$ model contain sufficient information to allow the linkage between valve closure behavior and $\mathrm{Na}^{+}$transport mechanism and to allow the predictions of (1) the $\mathrm{Cu}$ internalization flux as a function of bioavailable $\mathrm{Cu}^{2+}$-activity, (2) time-profile of internal sodium concentration, and (3) the relationships between sodium loss from clam and gill copper burden without any prior knowledge of the clam's physiological profile (Fig. 1C).

\section{Materials and methods}

The Cu-BLM framework applied to $C$. fluminea associated with the overall rates of uptake and loss of $\mathrm{Na}$ from the clam is diagrammed in Fig. 2. Our approach for developing a mechanistic model to predict the linkage between valve closure behavior and $\mathrm{Na}^{+}$transport mechanism in $C$. fluminea based on the concepts obtained from FIAM, BLM, and M-M kinetics is illustrated in Fig. 3 and is described in the subsequent sections.

\subsection{Cu-BLM-clam model}

In light of the concept of Cu-BLM framework (Fig. 2), a modified version of the basic Hill model equation (Liao et al., 2005) can be developed based on free $\mathrm{Cu}^{2+}$-activity and BLM-based EC50 model and is referred to as the Cu-BLM-clam model (Fig. 3A),

$R\left(\Delta t, \mathrm{Cu}^{2+}\right)=\frac{R_{\max } \times\left\{\mathrm{Cu}^{2+}\right\}^{n(\Delta t)}}{\left[\mathrm{EC} 50(\Delta t)_{\mathrm{CuBL}}\right]^{n(\Delta t)}+\left\{\mathrm{Cu}^{2+}\right\}^{n(\Delta t)}}$,

where $R\left(\Delta t, \mathrm{Cu}^{2+}\right)$ is the time-dependent valve response (\% response) based on $\mathrm{Cu}^{2+}$-activity $\left\{\mathrm{Cu}^{2+}\right\}(\mathrm{M})$ at any given clam response time $\Delta t, \operatorname{EC} 50(\Delta t)_{\mathrm{CuBL}}$ is the time-dependent BLM-predicted acute $\mathrm{Cu}$ EC50 value $(\mathrm{M}), R_{\max }$ is 

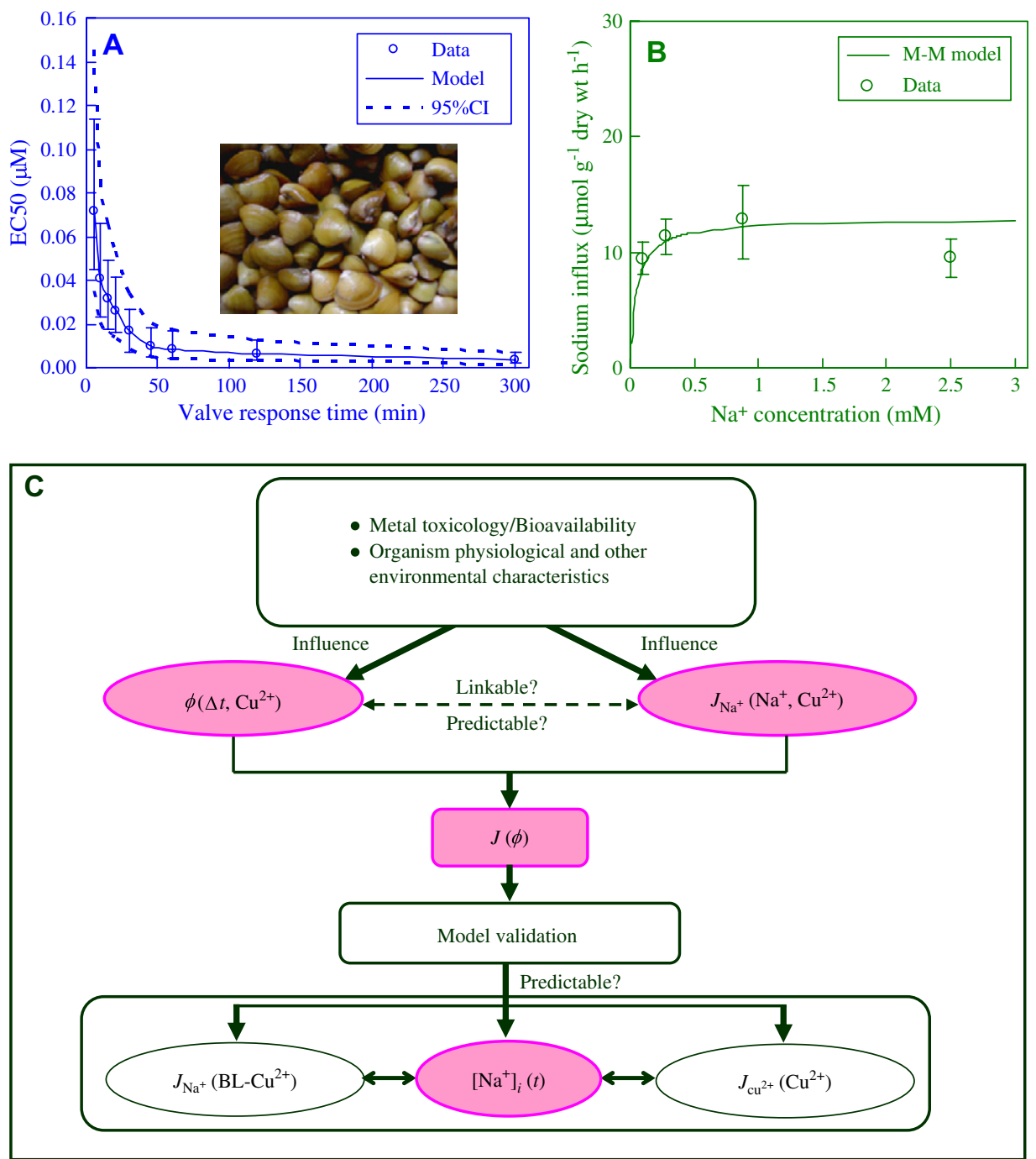

Fig. 1. Preliminary studies and the proposed "flux-biological response" hypothesis. (A) BLM-based response time-dependent EC50 values of valve closure behavior of $C$. fluminea in response to $\mathrm{Cu}$. (B) Na transport mechanism in $C$. fluminea follows the Michaelis-Menten kinetics, showing that maximum influx $J_{\text {max }}$ is $12.90 \pm 3.01 \mu \mathrm{mol} \mathrm{Na} \mathrm{g}{ }^{-1}$ dry tissue $\mathrm{h}^{-1}$ with a half-saturation affinity constant $K_{\mathrm{m}}$ of $0.05 \mathrm{mM}$ based on McCorkle and Dietz (1980). (C) Schematic of our "fluxbiological response" hypothesis in that $\phi\left(\Delta t, \mathrm{Cu}^{2+}\right)$ is the response time $(\Delta t)$ - and $\mathrm{Cu}^{2+}$-dependent valve closure response, $J_{\mathrm{Na}^{+}}\left(\Delta t, \mathrm{Cu}^{2+}, \mathrm{Na}^{+}\right)$is the $\mathrm{Na}^{+}$uptake rate, $J(\phi)$ is our proposed integrated model, $J_{\mathrm{Na}^{+}}\left(\mathrm{BL}-\mathrm{Cu}^{2+}\right)$ is gill $\mathrm{Cu}$ burden-based $\mathrm{Na}$ loss rate, $\left[\mathrm{Na}^{+}\right]_{\mathrm{i}}$ is the internal $\mathrm{Na}$ concentration, and $J_{\mathrm{Cu}^{2+}}\left(\mathrm{Cu}^{2+}\right)$ is the $\mathrm{Cu}$ internalization flux.

the maximum response $(\%)$, and $n(\Delta t)$ is a time-dependent Hill coefficient, which is a measure of cooperativity. A value of $n>1$ indicates positive cooperativity.

Based on the refined Cu-BLM scheme (De Schamphelaere et al., 2002), $\operatorname{EC} 50(\Delta t)_{\mathrm{CuBL}}$ in Eq. (1), taking into account the bioavailability and toxicities of $\mathrm{CuOH}^{+}$and $\mathrm{CuCO}_{3}$, has the form as,

$\operatorname{EC50}(\Delta t)_{\mathrm{CuBL}}=\frac{f_{\mathrm{CuBL}}^{50 \%}(\Delta t)}{\left(1-f_{\mathrm{CuBL}}^{50 \%}(\Delta t)\right)}\left(\frac{[b]}{[a]}\right)$,

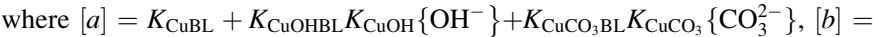
$1+K_{\mathrm{CaBL}}\left\{\mathrm{Ca}^{2+}\right\}+K_{\mathrm{MgBL}}\left\{\mathrm{Mg}^{2+}\right\}+K_{\mathrm{NaBL}}\left\{\mathrm{Na}^{+}\right\}+K_{\mathrm{HBL}}\left\{\mathrm{H}^{+}\right\}$in that $K_{\mathrm{CuBL}}$, $K_{\mathrm{CaBL}}, K_{\mathrm{MgBL}}, K_{\mathrm{NaBL}}, K_{\mathrm{HBL}}, K_{\mathrm{CuOHBL}}, K_{\mathrm{CuCO}_{3} \mathrm{BL}}$ are the stability constants for the binding of these cations to the $\mathrm{BL}\left(\mathrm{M}^{-1}\right) ; K_{\mathrm{CuOH}}$ and $K_{\mathrm{CuCO}_{3}}$ are the stability constants for the formations of the $\mathrm{CuOH}^{+}$and $\mathrm{CuCO}_{3}$, respectively $\left(\mathrm{M}^{-1}\right)$; and \{ion\} denotes the activity of each ion of water chemistry characteristics $(\mathrm{M})$, and $f_{\mathrm{CuBL}}^{50 \%}(\Delta t)$ is the time-dependent fraction of the total number of $\mathrm{Cu}$ binding sites occupied by $\mathrm{Cu}$ at $50 \%$ effect. The evaluation of Eq. (2) for predicting time-dependent EC50 values expressed as $\left\{\mathrm{Cu}^{2+}\right\}$ requires values of cation activities and known stability constants associated with the calculated fraction of the BL sites occupied by $\mathrm{Cu}$ Practically, Eq. (2) is integrated into WHAM scheme by adding stability constants for the binding of metal species (i.e., $\mathrm{Cu}^{2+}, \mathrm{CuOH}^{+}$, and $\left.\mathrm{CuCO}_{3}\right)$ and competing cations $\left(\mathrm{Ca}^{2+}, \mathrm{Mg}^{2+}, \mathrm{Na}^{+}\right.$, and $\left.\mathrm{H}^{+}\right)$onto the $\mathrm{BL}$ (Fig. 2). Through the linkage of Eqs. (1) and (2) and WHAM (WHAM VI, Centre for Ecology and Hydrology, Lancaster, UK) associated with calculated $f_{\mathrm{CuBL}}^{50 \%}(\Delta t)$ value that can be estimated by fitting Eq. (2) to the published EC50 $(\Delta t)$ data, we could predict a site-specific concentrationtime-response profile of valve closure behavior of $C$. fluminea in response to waterborne $\mathrm{Cu}$.

\subsection{Sodium transport-valve closure model}

To understand how the "flux analysis-biological response" structure determines the dynamics of biouptake and bioavailability, we built a mathematical model constrained by experimental observations. This model can be deliberately incorporated in both the $\mathrm{M}-\mathrm{M}$ kinetic model and the Cu-BLMclam model in Eq. (1) to obtain a sodium transport-valve closure response model denoting as $J(\phi)$ (Fig. 3B), 


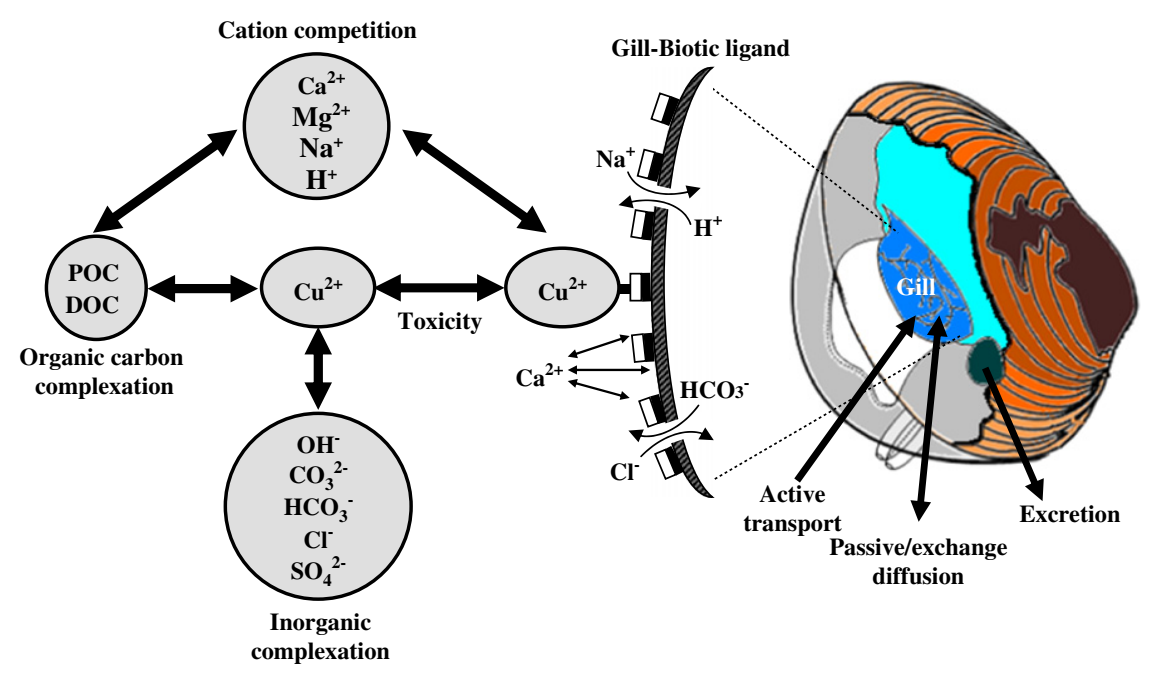

Fig. 2. Schematic diagram of the Cu-BLM framework applied to the freshwater clam $C$. fluminea associated with the overall rates of uptake and loss of Na from the clam. $\mathrm{POC}=$ particular organic carbon and DOC = dissolved organic carbon. (Modified from Paquin et al. (2002a,b) and Liao et al. (submitted for publication)).

$$
\begin{aligned}
J(\phi) \equiv J_{\mathrm{Na}^{+}}\left(\Delta t, \phi\left(\Delta t, \mathrm{Cu}^{2+}, \mathrm{Na}^{+}\right)\right) & =J_{\max } \times\left(1-I_{J_{\mathrm{Na}^{+}}}\left(\Delta t, \phi\left(\Delta t, \mathrm{Cu}^{2+}, \mathrm{Na}^{+}\right)\right)\right) \\
& =J_{\max } \times\left[1-\frac{1 \times \phi^{m(\Delta t)}}{\left[\operatorname{ER} 50_{\phi}(\Delta t)\right]^{m(\Delta t)}+\phi^{m(\Delta t)}}\right],
\end{aligned}
$$

where $\phi\left(\Delta t, \mathrm{Cu}^{2+}, \mathrm{Na}^{+}\right)$is a $\left\{\mathrm{Cu}^{2+}\right\}$-dependent clam valve closure response function taking into account external $\mathrm{Na}^{+}$activity and can be rewritten based on Eq. (1) as,

$\phi\left(\Delta t, \mathrm{Cu}^{2+}, \mathrm{Na}^{+}\right)=\frac{\phi_{\max } \times\left\{\mathrm{Cu}^{2+}\right\}^{n(\Delta t)}}{\left[c(\Delta t)+d(\Delta t)\left\{\mathrm{Na}^{+}\right\}\right]^{n(\Delta t)}+\left\{\mathrm{Cu}^{2+}\right\}^{n(\Delta t)}}$,

where $c(\Delta t)$ and $d(\Delta t)$ are the fitted parameters corresponding to $\operatorname{EC} 50(\Delta t)_{\mathrm{CuBL}}$, $J_{\max }$ is the M-M maximum $\mathrm{Na}^{+}$uptake rate in the absence of $\left\{\mathrm{Cu}^{2+}\right\}$ $\left(\mu \mathrm{mol} \mathrm{g}{ }^{-1} \mathrm{~h}^{-1}\right), m(\Delta t)$ is the response time-dependent Hill coefficient, $\mathrm{ER}_{50}(\Delta t)$ is the $50 \%$ effective response due to the \% inhibition of $\mathrm{Na}^{+}$uptake rate $I_{J_{\mathrm{Na}^{+}}}$that can be expressed by linking the $\mathrm{M}-\mathrm{M}$ kinetic model as,

$I_{J_{\mathrm{Na}^{+}}}=1-\frac{J_{\mathrm{Na}^{+}}\left(\Delta t, \mathrm{Cu}^{2+}, \mathrm{Na}^{+}\right)}{J_{\max }}$,

where the $\mathrm{Na}^{+}$uptake rate $J_{\mathrm{Na}^{+}}\left(\Delta t, \mathrm{Cu}^{2+}, \mathrm{Na}^{+}\right)$follows the $\mathrm{M}-\mathrm{M}$ kinetics,

$J_{\mathrm{Na}^{+}}\left(\Delta t, \mathrm{Cu}^{2+}, \mathrm{Na}^{+}\right)=\frac{J_{\max }\left(\left\{\mathrm{Cu}^{2+}\right\}\right) \times\left\{\mathrm{Na}^{+}\right\}}{K_{\mathrm{m}}\left(\Delta t,\left\{\mathrm{Cu}^{2+}\right\}\right)+\left\{\mathrm{Na}^{+}\right\}}$,

where $\left\{\mathrm{Cu}^{2+}\right\}$-dependent $J_{\max }\left(\left\{\mathrm{Cu}^{2+}\right\}\right)$ and response time- and $\left\{\mathrm{Cu}^{2+}\right\}$-dependent half-saturation affinity constant $K_{\mathrm{m}}\left(\Delta t,\left\{\mathrm{Cu}^{2+}\right\}\right)$ can be obtained by fitting Eq. (6) to the data predicted from our proposed model in Eq. (3) subjected to various external $\left\{\mathrm{Cu}^{2+}\right\}$.

\subsection{Physiological processes predictions}

Here, we link $\mathrm{Cu}$ biodynamics with transport physiology in the $C$. fluminea (Fig. 3C). Grosell et al. (2002) suggested that the internal sodium concentration decays exponentially if sodium uptake is inhibited,

$[\mathrm{Na}]_{\mathrm{i}}(t)=[\mathrm{Na}]_{\mathrm{i}}(0) \exp (-k t)$,

where $[\mathrm{Na}]_{\mathrm{i}}$ is the internal $\mathrm{Na}$ concentration $\left(\mu \mathrm{mol} \mathrm{g}^{-1}\right)$ and the decay rate constant $k\left(\mathrm{~h}^{-1}\right)$ is defined as,
$k=\frac{I_{J_{\mathrm{Na}}+} J_{\mathrm{Na}^{+}}\left(\Delta t, \mathrm{Cu}^{2+}, \mathrm{Na}^{+}\right)}{[\mathrm{Na}]_{\mathrm{i}}(0)}$.

To obtain the relationships between $\mathrm{Na}$ uptake and gill $\mathrm{Cu}$ burden, we use fraction of the total number of $\mathrm{Cu}$ binding sites occupied by $\mathrm{Cu}\left(f_{\mathrm{CuBL}}\right)$ to represent the $\mathrm{BL}-\mathrm{Cu}$ burden in that $f_{\mathrm{CuBL}}$ is given by (De Schamphelaere et al., 2002),

$f_{\mathrm{CuBL}}=\frac{\left([a]\left\{\mathrm{Cu}^{2+}\right\}\right)\left[\mathrm{BL}^{-}\right]}{\left([a]\left\{\mathrm{Cu}^{2+}\right\}+[b]\right)\left[\mathrm{BL}^{-}\right]}$.

We incorporate Eq. (9) into Eq. (4) to obtain the relationships between $f_{\mathrm{CuBL}}$ and $\phi\left(\Delta t, \mathrm{Cu}^{2+}\right)$ as $f_{\mathrm{CuBL}}(\Delta t, \phi)$. Finally, the relationships between the inhibition of $\mathrm{Na}$ uptake and $\mathrm{BL}-\mathrm{Cu}$ expressed by $f_{\mathrm{CuBL}}$ can be derived by incorporating $f_{\mathrm{CuBL}}(\Delta t, \phi)$ into $J(\phi)$ model in Eq. (3) and expressed as a Hill model,

$I_{J_{\mathrm{Na}^{+}}}\left(\Delta t, f_{\mathrm{CuBL}}\right)=\frac{f_{\mathrm{CuBL}}^{v(\Delta t)}}{\left[\operatorname{ER} 50_{f}(\Delta t)\right]^{v(\Delta t)}+f_{\mathrm{CuBL}}^{v(\Delta t)}}$,

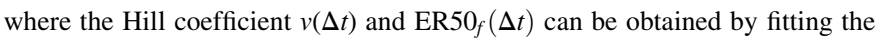
model to the data.

The concentration of unoccupied gill-BL sites can be estimated by linking the gill $\mathrm{Cu}$ burden $[\mathrm{CuBL}]$ in the BLM scheme (De Schamphelaere et al., 2002) and a one-compartment uptake-elimination model at a steady-state condition (Croteau et al., 2004),

$$
\begin{aligned}
{[\mathrm{CuBL}]_{\mathrm{T}} } & =\left[\mathrm{CuBL}^{+}\right]+\left[\mathrm{CuOHBL}^{0}\right]+\left[\mathrm{CuCO}_{3} \mathrm{BL}^{-}\right] \\
& =\left[\mathrm{BL}^{-}\right][a]\left\{\mathrm{Cu}^{2+}\right\} \approx \frac{k_{1}}{k_{2}}\left\{\mathrm{Cu}^{2+}\right\}
\end{aligned}
$$

where $[\mathrm{CuBL}]_{\mathrm{T}}$ is the steady-state gill $\mathrm{Cu}-\mathrm{BL}$ burden $\left(\mu \mathrm{mol} \mathrm{g}^{-1}\right),\left[\mathrm{BL}^{-}\right]$is the concentration of unoccupied gill BL sites $\left(\mu \mathrm{mol} \mathrm{g}^{-1}\right)$, and $k_{1}\left(\mathrm{~L} \mathrm{~g}^{-1} \mathrm{~d}^{-1}\right)$ and $k_{2}\left(\mathrm{~d}^{-1}\right)$ are the uptake and depuration rate constants, respectively. Based on Eq. (11), we can directly estimate $\left[\mathrm{BL}^{-}\right]$from the knowledge of $k_{1} / k_{2}$ and $[a]$ provided by published data as $\left[\mathrm{BL}^{-}\right]=\left(k_{1} / k_{2}\right) /[a]$ (Croteau and Luoma, 2005). By the definition of $\mathrm{Cu}$ internalization flux as $J_{\mathrm{Cu}^{2+}} \equiv[\mathrm{CuBL}]_{\mathrm{T}} / \Delta t$ and under a steady-state condition, the $\mathrm{Cu}$ internalization flux as a function of external bioavailable $\left\{\mathrm{Cu}^{2+}\right\}$ can be given by a M-M kinetics as,

$J_{\mathrm{Cu}^{2+}} \equiv \frac{[\mathrm{CuBL}]_{\mathrm{T}}}{\Delta t}=\frac{J_{\mathrm{Cu}^{2+}, \max }\left\{\mathrm{Cu}^{2+}\right\}}{K_{\mathrm{m}, \mathrm{Cu}^{2+}}+\left\{\mathrm{Cu}^{2+}\right\}}$

where $J_{\mathrm{Cu}^{2+}, \text { max }}=\left[\mathrm{BL}^{-}\right] / \Delta t=\left(k_{1} / k_{2}\right)[a]^{-1} / \Delta t$ is the $\mathrm{M}-\mathrm{M}$ maximum $\mathrm{Cu}^{2+}$ uptake rate $\left(\mu \mathrm{mol} \mathrm{g} \mathrm{g}^{-1} \mathrm{~h}^{-1}\right)$ and $K_{\mathrm{m}, \mathrm{Cu}^{2+}}$ is a half-saturation affinity constant 


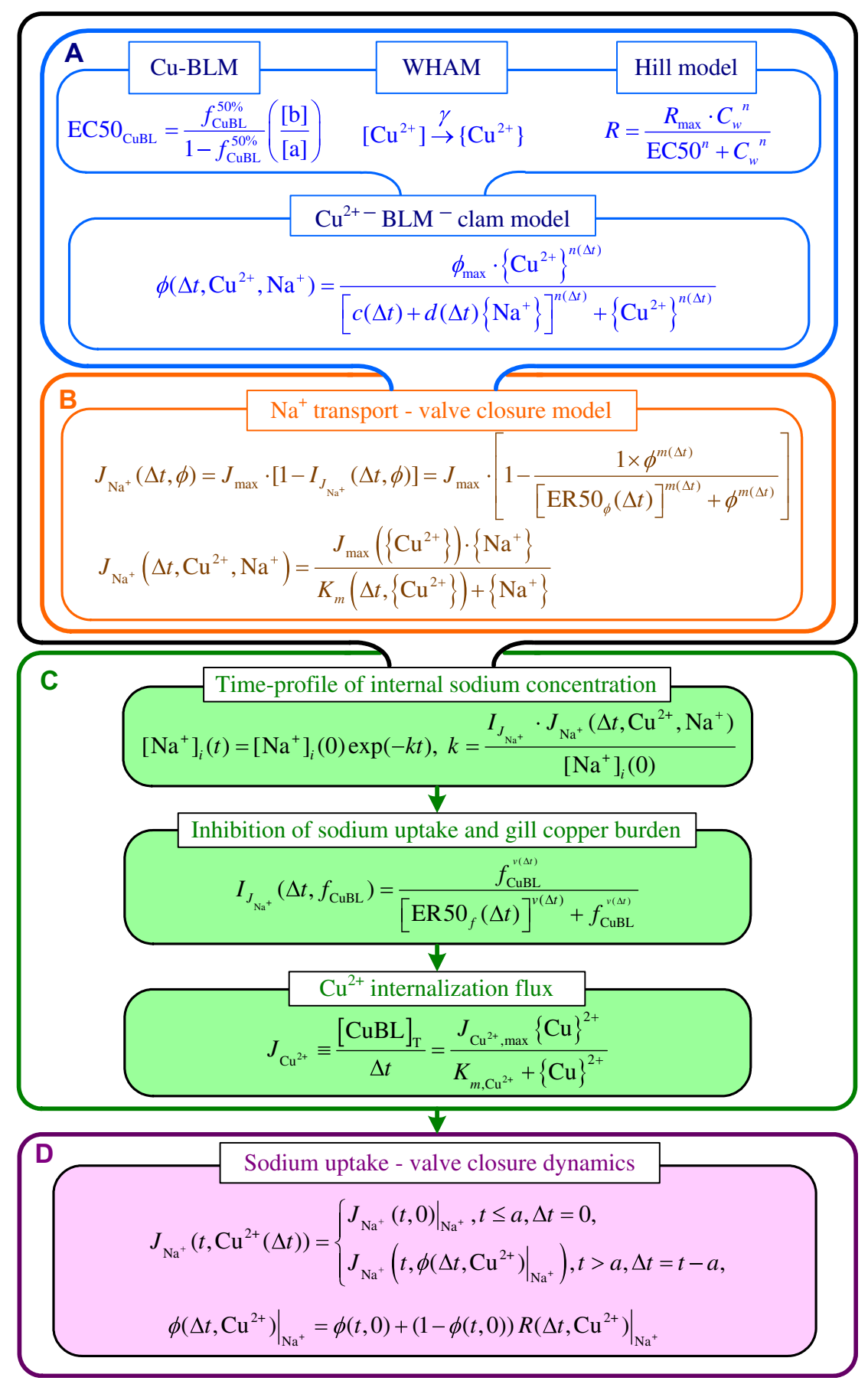

Fig. 3. A conceptual algorithm showing a mechanistic model to predict the linkage between valve closure behavior and Na transport mechanism in $C$. fluminea. (See text for detail descriptions of symbol).

$(\mu \mathrm{M})$ that can be estimated from a limiting diffusion flux of free metal expressing as a linear function (Jansen et al., 2002),

$J_{\mathrm{Cu}^{2+}, \mathrm{diff}}=\frac{\left[\mathrm{BL}^{-}\right]\left[a^{\prime}\right]\left\{\mathrm{Cu}^{2+}\right\}}{\Delta t}=\frac{\left(k_{1} / k_{2}\right)[a]^{-1}\left[a^{\prime}\right]\left\{\mathrm{Cu}^{2+}\right\}}{\Delta t}$,

where $J_{\mathrm{Cu}^{2+} \text {,diff }}$ is a diffusion-limited Cu-uptake rate and $\left[a^{\prime}\right]$ can be obtained from the published water chemistry characteristics by McCorkle and Dietz (1980). Finally, by linking $\mathrm{Na}^{+}$uptake rate $J_{\mathrm{Na}^{+}}\left(\Delta t, \mathrm{Cu}^{2+}, \mathrm{Na}^{+}\right)$in Eq. (6) with Eq. (12), we can capture the relationships between $\mathrm{Na}$ uptake and $\mathrm{Cu}$ internalization flux expressed as $J_{\mathrm{Na}^{+}}(\Delta t)-J_{\mathrm{Cu}^{2+}}$ profile varied by different external $\left\{\mathrm{Na}^{+}\right\}$.

\subsection{Sodium uptake-valve closure dynamics}

We link the $J(\phi)$ model shown in Eq. (3) and the fitted model of clam valve opening/closing daily rhythm to predict the $\mathrm{Na}$ uptake and bivalve closure behavior dynamics in response to waterborne $\mathrm{Cu}$ (Fig. 3D),

$J_{\mathrm{Na}^{+}}\left(t, \mathrm{Cu}^{2+}(\Delta t)\right)=\left\{\begin{array}{l}\left.J_{\mathrm{Na}^{+}}(t, 0)\right|_{\mathrm{Na}^{+}}=J_{\mathrm{max}}, \quad t \leq a, \Delta t=0, \\ J_{\mathrm{Na}^{+}}\left(t,\left.\phi\left(\Delta t, \mathrm{Cu}^{2+}\right)\right|_{\mathrm{Na}^{+}}\right), \quad t>a, \Delta t=t-a,\end{array}\right.$

and the valve closure behavior dynamics can be predicted as,

$\left.\phi\left(t, \mathrm{Cu}^{2+}\right)\right|_{\mathrm{Na}^{+}}=\phi(t, 0)+\left.(1-\phi(t, 0)) R\left(\Delta t, \mathrm{Cu}^{2+}\right)\right|_{\mathrm{Na}^{+}}$, 
where $\left.\phi\left(\Delta t, \mathrm{Cu}^{2+}\right)\right|_{\mathrm{Na}^{+}}$is the valve closure daily rhythm at time $t$ in response to $\left\{\mathrm{Cu}^{2+}\right\}$ subjected to a specific external $\left\{\mathrm{Na}^{+}\right\}, a$ is an initiation time of clam in response to waterborne $\mathrm{Cu}$, and $\phi(t, 0)$ is the daily rhythm function of valve closure exposed to unpolluted water and has the form modeled as a three-parameter lognormal model (Liao et al., 2005),

$$
\begin{aligned}
& \phi(t, 0)= \\
& \left\{\begin{array}{l}
\phi_{1}(t, 0)=12.3 \exp \left[-0.5(\ln (t / 4) / 0.20)^{2}\right]+3.8, \quad 0 \leq t \leq 7, r^{2}=0.84, \\
\phi_{2}(t, 0)=14.8 \exp \left[-0.5(\ln (t / 18.2) / 0.083)^{2}\right]+3.6, \quad 7 \leq t \leq 24, r^{2}=0.92 .
\end{array}\right.
\end{aligned}
$$

Eq. (16) has a bimodal distribution that is separated at 07:00 a.m. based on the suggestion by Tran et al. (2003).

\section{Results}

\subsection{Clam Na uptake predictions in response to $\mathrm{Cu}$}

The reconstructed clam valve closure response function incorporating external $\mathrm{Na}^{+}$activity can be obtained by fitting $\phi\left(\Delta t, \mathrm{Cu}^{2+}, \mathrm{Na}^{+}\right)$in Eq. (4) to the reported data of response time-specific concentration-\% valve closure response profiles (Tran et al., 2004), resulting in the fitted parameters of $n(\Delta t)=1.221+0.988 \exp (-\Delta t / 37.703) \quad\left(r^{2}=0.89\right), \quad c(\Delta t)=$ $1.05 \times 10^{-8}+6.44 \times 10^{-8} \exp (-\Delta t / 31.743) \quad\left(r^{2}=0.99\right)$, and $d(\Delta t)=4.46 \times 10^{-6}+2.76 \times 10^{-5} \exp (-\Delta t / 31.75)\left(r^{2}=0.99\right)$. Linking estimated $\phi\left(\Delta t, \mathrm{Cu}^{2+}, \mathrm{Na}^{+}\right)$with fitted $\mathrm{M}-\mathrm{M}$ kinetic model from McCorkle and Dietz (1980) (Fig. 1B), the fitted parameters in $\mathrm{Na}$ transport-valve closure model in Eq. (3) are estimated to be: $m(\Delta t)=24.33-778.43 / \Delta t\left(r^{2}=0.97\right)$ and $\mathrm{ER} 0_{\phi}(\Delta t)=84.15-1103.27 / \Delta t\left(r^{2}=0.95\right)$. Table 1 gives the reported data of used water chemistry characteristics employed in our study.

The result shows that the proposed $J(\phi)$ model (Eq. (3)) agrees well with the $\mathrm{Na}$ uptake profile in the absence of $\mathrm{Cu}$ (Fig. 4A). Based on our $J(\phi)$ model, we can straightforwardly predict the Na uptake profiles as a function of external $\mathrm{Na}^{+}$activity varied with different waterborne $\mathrm{Cu}^{2+}$ concentrations ranging from $1-20 \mu \mathrm{gL}^{-1}$ (Fig. 4B) in that the $\mathrm{Na}^{+}$uptake rate $J_{\mathrm{Na}^{+}}\left(\Delta t, \mathrm{Cu}^{2+}, \mathrm{Na}^{+}\right)$has a $\mathrm{M}-\mathrm{M}$ kinetics shown in Eq. (6) in that $\left\{\mathrm{Cu}^{2+}\right\}$-dependent maximum uptake rates and half-saturation affinity constants can be, respectively, estimated to be,

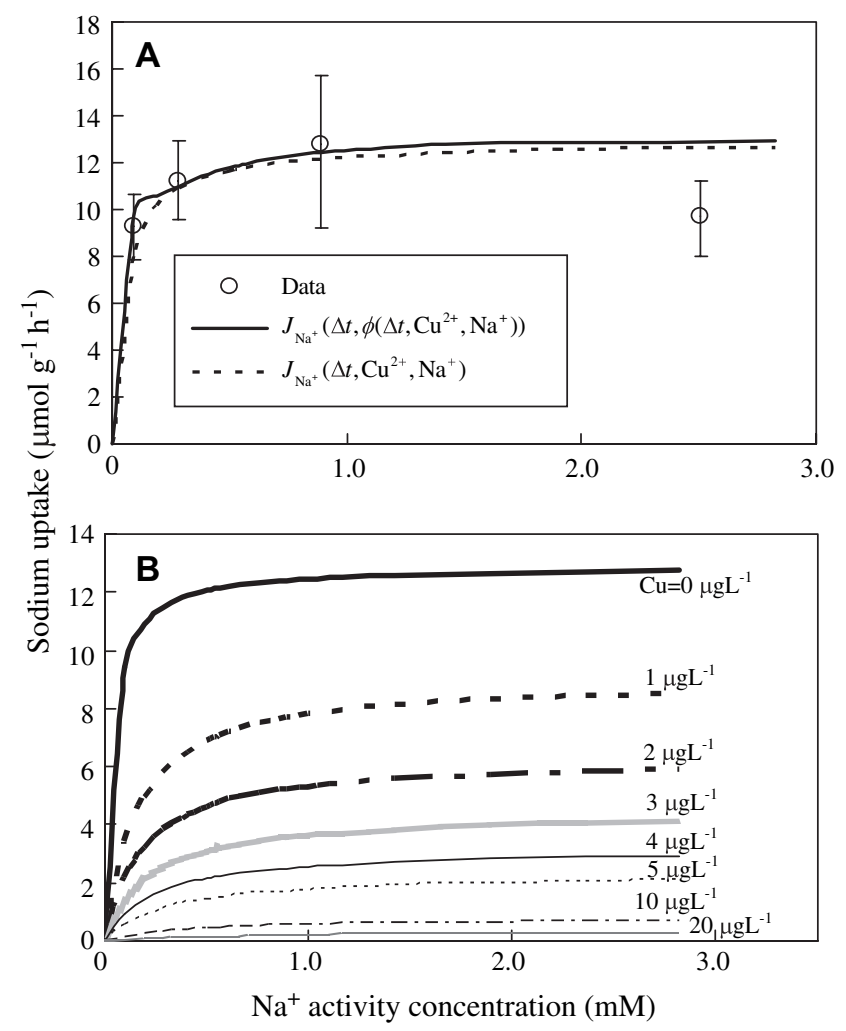

Fig. 4. Clam Na uptake prediction in response to $\mathrm{Cu}$. (A) Validation of our proposed model of (i) response in valve closure behavior depends on external $\mathrm{Cu}$ and $\mathrm{Na}$ activity concentrations by Eq. (3) and (ii) a modeled $\mathrm{M}-\mathrm{M}$ kinetics by Eq. (6) agrees well with the Na uptake profile in the absence of $\mathrm{Cu}$ estimated by McCorkle and Dietz (1980). (B) Predicted Na uptake rate in response to waterborne $\mathrm{Cu}$ of $0,1,2,3,4,5,10$, and $20 \mu \mathrm{g} \mathrm{L}^{-1}$, respectively.

$$
\begin{gathered}
J_{\max }\left(\left\{\mathrm{Cu}^{2+}\right\}\right)=0.345+12.90 \times \exp \left(-\left\{\mathrm{Cu}^{2+}\right\} / 6.154 \times 10^{-8}\right), \\
r^{2}=0.85,
\end{gathered}
$$

$K_{\mathrm{m}}\left(\Delta t,\left\{\mathrm{Cu}^{2+}\right\}\right)=a_{1}(\Delta t)\left\{\mathrm{Cu}^{2+}\right\}^{a_{2}(\Delta t)}$,

where $a_{1}(\Delta t)=3.84+193.66 \times \exp (-\Delta t / 136.23)\left(r^{2}=0.99\right)$ and $a_{2}(\Delta t)=0.862 \times \exp (-\Delta t / 2875.88)\left(r^{2}=0.68\right)$. Fig. $4 \mathrm{~A}$ also demonstrates that derived $\mathrm{Na}^{+}$uptake rate model of $J_{\mathrm{Na}^{+}}\left(\Delta t, \mathrm{Cu}^{2+}, \mathrm{Na}^{+}\right)$also has a good fit with the published

\begin{tabular}{|c|c|c|c|c|c|}
\hline $\begin{array}{l}\text { Water chemistry } \\
\text { characteristics }\end{array}$ & $\begin{array}{l}\text { Tran et al. } \\
(2004)\end{array}$ & $\begin{array}{l}\text { McCorkle and } \\
\text { Dietz (1980) }\end{array}$ & $\begin{array}{l}\text { Marr et al. } \\
\text { (1998) }\end{array}$ & $\begin{array}{l}\text { Matsuo et al. } \\
\text { (2004) }\end{array}$ & $\begin{array}{l}\text { Croteau and } \\
\text { Luoma (2005) }\end{array}$ \\
\hline $\mathrm{pH}$ & 8.2 & 7.2 & 7.5 & 7.8 & 6 \\
\hline Temperature $\left({ }^{\circ} \mathrm{C}\right)$ & 15 & 25 & 9.8 & 12 & 15 \\
\hline$\left[\mathrm{Ca}^{2+}\right](\mathrm{mM})$ & 0.24 & 0.4 & 0.14 & 0.10 & 0.048 \\
\hline$\left[\mathrm{Mg}^{2+}\right](\mathrm{mM})$ & 0.16 & 0.20 & 0.12 & 0.15 & 0.062 \\
\hline$\left[\mathrm{Na}^{+}\right](\mathrm{mM})$ & 1.4 & 0.70 & 0.039 & 0.60 & 0.14 \\
\hline$\left[\mathrm{K}^{+}\right](\mathrm{mM})$ & 0.092 & 0.05 & 0.10 & 0.05 & 0.0067 \\
\hline$\left[\mathrm{CO}_{3}^{2-}\right](\mathrm{mM})$ & 0.35 & 0.00018 & - & 0.90 & 0.14 \\
\hline$\left[\mathrm{SO}_{4}^{2-}\right](\mathrm{mM})$ & 0.037 & - & 0.037 & - & 0.11 \\
\hline$\left[\mathrm{Cl}^{-}\right](\mathrm{mM})$ & 1.0 & 1.4 & 0.02 & 0.70 & 0.0067 \\
\hline
\end{tabular}
data in the absence of $\mathrm{Cu}$.

Table 1

Published data of water chemistry characteristics used in the study 


\subsection{Validation of $J(\phi)$ model}

We further test the present $J(\phi)$ model to the reported experimental observations of $\mathrm{Na}$ uptake kinetics in rainbow trout to validate the model. We reconstruct the response time-specific mortality-Cu profiles adapted from Marr et al. (1998) (Fig. 5A) and $\mathrm{Na}$ uptake profiles varied with different $\mathrm{Cu}$ concentrations reanalyzed from Matsuo et al. (2004) (Fig. 5B) associated with the reported water chemistry characteristics (Table 1), we can obtain a relationship between mortality and inhibition of Na uptake $I_{J_{\mathrm{Na}}+}$ expressed as a Hill model (Fig. 5C). Based on the proposed $J(\phi)$ model incorporated with Fig. 5A-C, the model test results show that the predicted $\mathrm{M}-\mathrm{M}$ type $\mathrm{Na}$ uptake profiles in response to waterborne $\mathrm{Cu}$ ranging from $0-300 \mu \mathrm{g} \mathrm{L}^{-1}$ agree well with the published data with an average root mean square error of predictions $77 \mathrm{nmol} \mathrm{g}^{-1} \mathrm{~h}^{-1}$ (Fig. 5D and Table 2). Thus, our validation (Fig. 5D) confirms that the predictive model for Na uptake kinetics in response to waterborne $\mathrm{Cu}$ is robust.

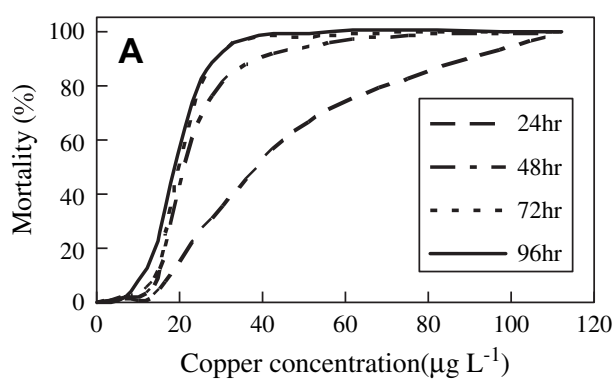

\subsection{Model predictability of transport physiology}

The predictability of our proposed model is reflected on predicting three transport physiological processes of $C$. fluminea: (1) time-profile of internal $\mathrm{Na}^{+}$concentration, (2) $\mathrm{Na}^{+}$uptake as a function of gill $\mathrm{Cu}$ burden, and (3) $\mathrm{Cu}^{2+}$ internalization flux.

The time-profile of internal $\mathrm{Na}$ concentration in C. fluminea in response to waterborne $\mathrm{Cu}$ can be well predicted based on our present $J(\phi)$ model (Fig. 6A), whereas the relationships between valve closure response and internal $\mathrm{Na}$ concentration can also be depicted (Fig. 6B). Our simulation assumes that $\mathrm{Na}^{+}$uptake equals the diffusive $\mathrm{Na}$ loss associated with a change in uptake by an inhibition parameter $I_{J_{\mathrm{Na}^{+}}}$(Eq. (8)). Fig. 6 indicates that $\%$ valve closure response will decrease for clam with higher internal sodium concentration. The inversion of decay rate constant $k$ in Eq. (8) can be defined as the time constant $\tau$, indicating that \% valve closure response will occur earlier in clam with higher relative inhibition of sodium uptake.
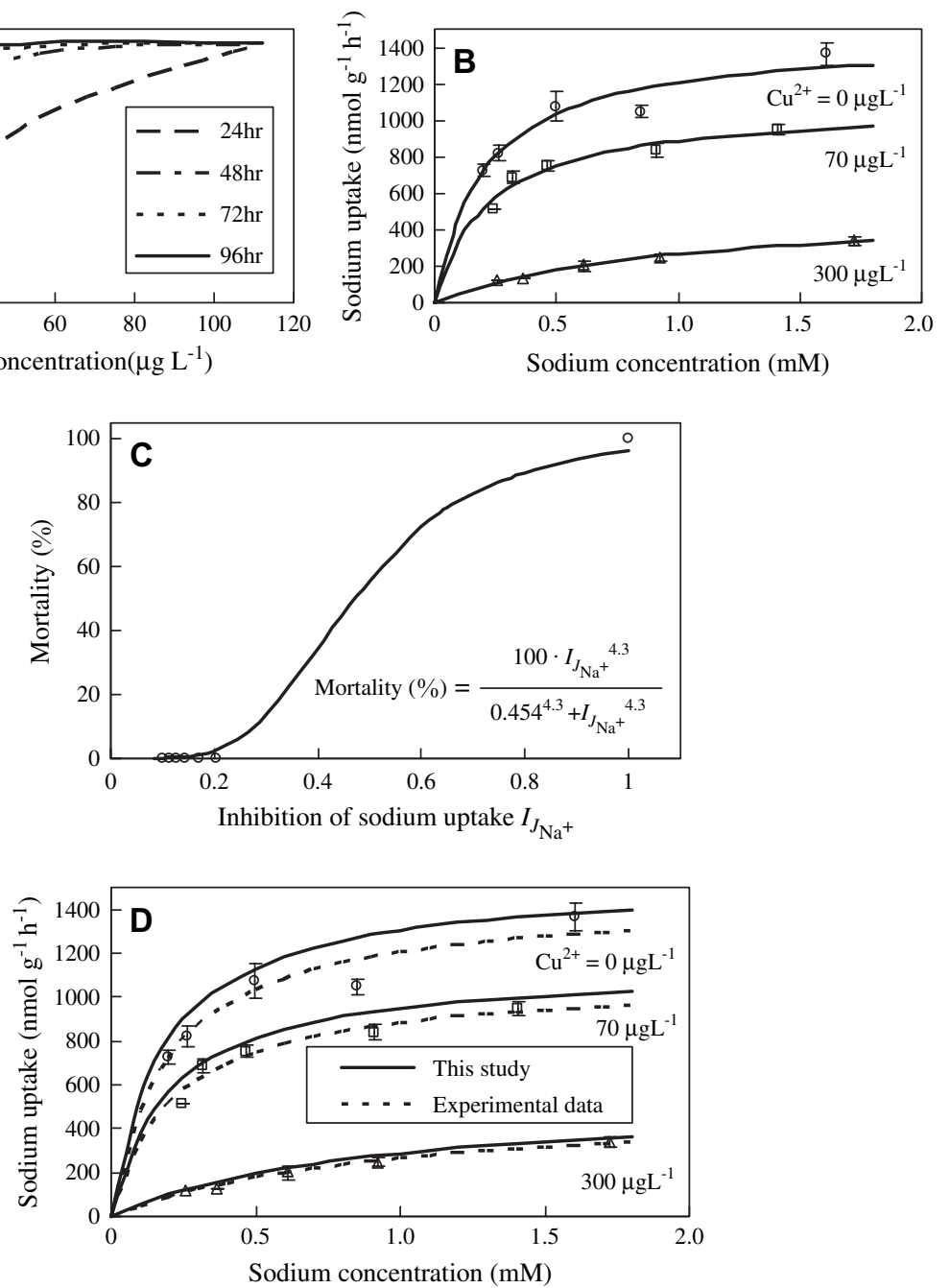

Fig. 5. Validation of $J(\phi)$ model to the reported data of Na uptake kinetics in rainbow trout. (A) Reconstructed Cu concentration-mortality profile at $24,48,72$, and $96 \mathrm{~h}$, respectively based on Marr et al. (1998). (B) Published M-M Na uptake profiles in response to Cu concentrations of 0, 70, and $300 \mu \mathrm{g} \mathrm{L}{ }^{-1}$ based on Matsuo et al. (2004). (C) By linking BLM-based dose-response and Na uptake mechanism into our proposed model to predict the relationship between inhibition of Na uptake and mortality as a Hill model. (D) Model validation results show that our predicted M-M kinetics agrees well with the published data. 
Table 2

A comparison of M-M kinetics-based $J_{\max }$ and $K_{\mathrm{m}}$ value between experimental data (mean $\pm \mathrm{SD}$ ) and predictions by the present model applied to sodium uptake profile of rainbow trout varied with different $\mathrm{Cu}$ concentrations

\begin{tabular}{lllll}
\hline $\begin{array}{l}\text { Copper } \\
\text { concentration } \\
\left(\mu \mathrm{g} \mathrm{L}^{-1}\right)\end{array}$ & $\begin{array}{l}J_{\max } \\
\left(\mathrm{nmol} \mathrm{g}^{-1} \mathrm{~h}^{-1}\right)\end{array}$ & $\begin{array}{l}K_{\mathrm{m}} \\
\left(\mathrm{mM} \mathrm{Na}^{+}\right)\end{array}$ & $r^{2}$ & $\begin{array}{l}\text { RMSE } \\
\left(\mathrm{nmol} \mathrm{g}^{-1} \mathrm{~h}^{-1}\right)^{\mathrm{b}}\end{array}$ \\
\hline $\begin{array}{l}\text { Experimental data } \\
\text { a }\end{array}$ & $1453 \pm 116$ & $0.204 \pm 0.058$ & 0.91 & \\
$\quad 0$ & $1082 \pm 72$ & $0.221 \pm 0.051$ & 0.93 & \\
70 & $522 \pm 30$ & $0.967 \pm 0.010$ & 0.99 & \\
300 & & & & \\
\multicolumn{7}{l}{$\begin{array}{llll}\text { Model prediction } \\
0\end{array}$} & 1540 & 0.180 & 0.99 & 117.3 \\
70 & 1140 & 0.200 & 0.99 & 63.5 \\
300 & 550 & 0.912 & 0.94 & 14.7 \\
\hline
\end{tabular}

${ }^{a}$ Adapted from Matsuo et al. (2004).

${ }^{\mathrm{b}}$ Root mean square error of predictions (RMSE) $=\sqrt{\sum_{n=1}^{N}\left(C_{\mathrm{m}, n}-C_{\mathrm{s}, n}\right)^{2} / N}$ where $N$ denotes the number of measurements, $C_{\mathrm{m}, n}$ is the measurement data, and $C_{\mathrm{s}, n}$ is the simulation result corresponding to data point $n$.

Followed by the BLM scheme in Eq. (9), we can obtain a relationship between the fraction of the total number of $\mathrm{Cu}$ binding sites occupied by $\mathrm{Cu}\left(f_{\mathrm{CuBL}}\right)$ and external bioavailable $\mathrm{Cu}$ activity (Fig. 7A) based on the reported water chemistry characteristics from McCorkle and Dietz (1980) (Table 1). We incorporate Fig. 7A into published concentration-\% valve closure response profiles expressed by Eq. (4) to estimate a response time-specific $f_{\mathrm{CuBL}}-\phi\left(\Delta t, \mathrm{Cu}^{2+}\right)$ relationship as $f_{\text {CuBL }}(\Delta t, \phi)=-0.109+(0.0068 \phi)+0.571 \exp (-\Delta t / 38.24)$ $\left(r^{2}=0.98\right)$. We integrate estimated $f_{\mathrm{CuBL}}(\Delta t, \phi)$ into the present $J(\phi)$ model in Eq. (3) to capture the relationships between the inhibition of $\mathrm{Na}$ uptake and $\mathrm{BL}-\mathrm{Cu}$ expressed by $f_{\mathrm{CuBL}}$ as a Hill model (Eq. (10)) where fitted parameters of $v(\Delta t)=18.457-411.744 / \Delta t\left(r^{2}=0.99\right)$ and $\operatorname{ER} 50_{f}(\Delta t)=$ $0.421+1.853 / \Delta t \quad\left(r^{2}=0.94\right)$ (Fig. 7B). We validate the derived $J_{\mathrm{Na}^{+}}\left(\Delta t, f_{\mathrm{CuBL}}\left(\Delta t, \phi\left(\Delta t, \mathrm{Cu}^{2+}, \mathrm{Na}^{+}\right)\right)\right)$model to the published $\mathrm{Na}$ uptake profile in $C$. fluminea, showing a good agreement not only with the data but also with the other two models of $J_{\mathrm{Na}^{+}}\left(\Delta t, \mathrm{Cu}^{2+}, \mathrm{Na}^{+}\right)$in Eq. (6) and $J_{\mathrm{Na}^{+}}(\Delta t$, $\left.\phi\left(\Delta t, \mathrm{Cu}^{2+}, \mathrm{Na}^{+}\right)\right)($Fig. 7C).

We adapt published $k_{1}$ and $k_{2}$ values of $\mathrm{Cu}$ accumulation and elimination in $C$. fluminea $\left(k_{1}=0.224 \pm 0.038 \mathrm{~L} \mathrm{~g}^{-1} \mathrm{~d}^{-1}\right.$

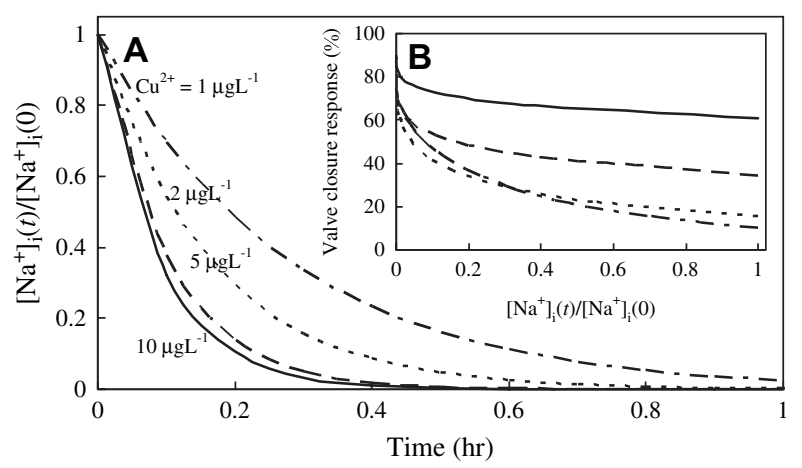

Fig. 6. (A) Time-dependent internal $\mathrm{Na}^{+}$concentration in $C$. fluminea in response to waterborne $\mathrm{Cu}$ of $1,2,5$, and $10 \mu \mathrm{g} \mathrm{L}{ }^{-1}$ corresponding to decay rate constants $k$ of $3.64,6.14,9.80$, and $11.24 \mathrm{~h}^{-1}$, respectively. (B) Relationship between valve closure responses and internal $\mathrm{Na}$ concentration.
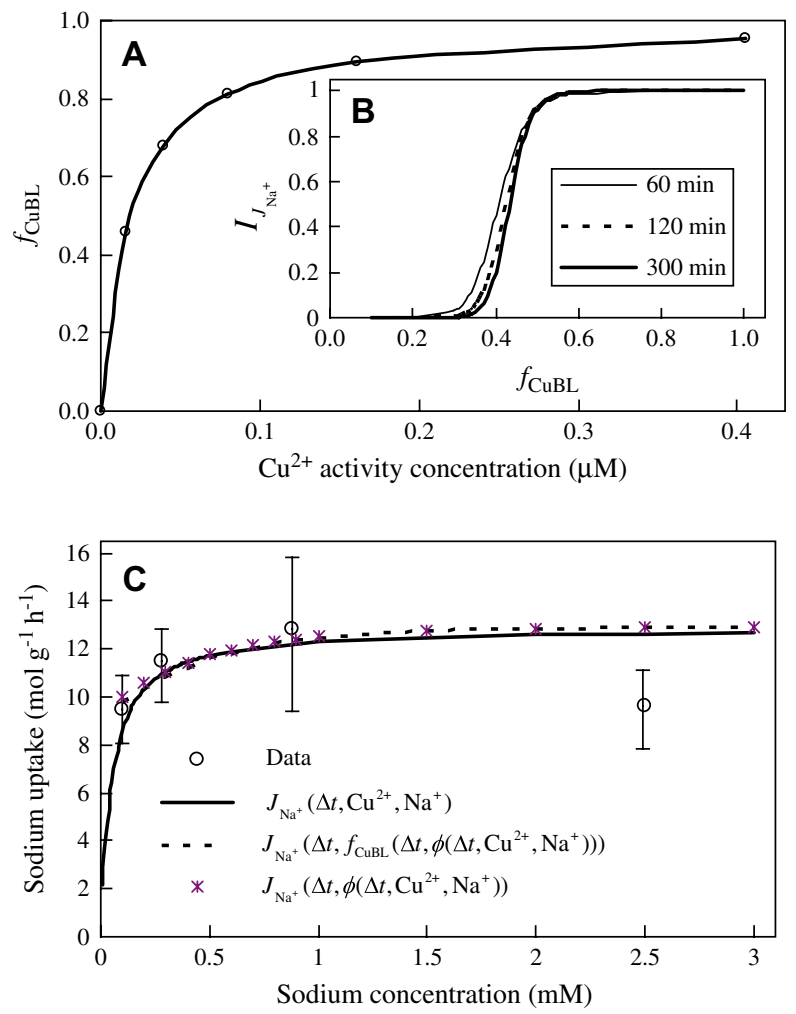

Fig. 7. (A) BLM-based predicted relationship between the fraction of the total number of $\mathrm{Cu}$ binding sites occupied $\left(f_{\mathrm{CuBL}}\right)$ and external $\mathrm{Cu}$ activity based on the reported water chemistry characteristics from McCorkle and Dietz (1980). (B) Response time-specific response profile of inhibition of Na uptake and $f_{\text {CuBL }}$ expressed as a Hill model. (C) Validation of the derived $J_{\mathrm{Na}^{+}}\left(\Delta t, f_{\mathrm{CuBL}}\left(\Delta t, \phi\left(\mathrm{Cu}^{2+}, \mathrm{Na}^{+}\right)\right)\right)$model with published $\mathrm{Na}$ transport profile in $C$. fluminea in the absence of $\mathrm{Cu}\left(r^{2}=0.91\right)$.

and $k_{2}=0.004 \pm 0.054 \mathrm{~d}^{-1}$ ) associated with the reported water chemistry data from Croteau and Luoma (2005) (Table 1) to estimate $\left[\mathrm{BL}^{-}\right]$based on Eq. (11), resulting in $\left[\mathrm{BL}^{-}\right]=$ $1.107 \mu \mathrm{mol} \mathrm{g}^{-1}$ with a $95 \%$ confidence interval (CI) of 0.780-1.524 performed by the Monte Carlo simulation technique. Thus, $J_{\mathrm{Cu}^{2+}, \text { max }}=\left[\mathrm{BL}^{-}\right] / \Delta t=\left(k_{1} / k_{2}\right)[a]^{-1} / \Delta t=$ $0.369(95 \% \mathrm{CI}: 0.26-0.51) \mu \mathrm{mol} \mathrm{g}{ }^{-1} \mathrm{~h}^{-1}$ where the response time $\Delta t=3 \mathrm{~h}$. The half-saturation affinity constant $K_{\mathrm{m}, \mathrm{Cu}^{2+}}$ can

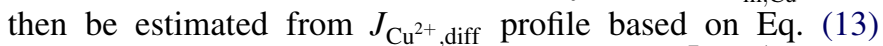
(Fig. 8B) where $\left[a^{\prime}\right]$ is estimated to be $6.35 \times 10^{7} \mathrm{M}^{-1}$, resulting in $K_{\mathrm{m}, \mathrm{Cu}^{2+}}=7.87 \times 10^{-3}\left(95 \% \mathrm{CI}: 5.72 \times 10^{-3}-11.2 \times\right.$ $\left.10^{-3}\right) \mu \mathrm{M}$. The $\mathrm{Cu}$ internalization flux profile as a function of external $\left\{\mathrm{Cu}^{2+}\right\}$, therefore, can be predicted by Eq. (12) based on the reported water chemistry data from McCorkle and Dietz (1980) (Fig. 8A). We finally predict the relationships between $\mathrm{Na}$ uptake and $\mathrm{Cu}$ internalization flux by linking Eq. (6) as illustrated in Fig. 4B and Eq. (13) to depict the $J_{\mathrm{Na}^{+}}(\Delta t)-J_{\mathrm{Cu}^{2+}}$ profile (Fig. 8C).

\subsection{Na uptake-valve closure dynamics}

The dynamic behavior of clam valve closure behavior associated with $\mathrm{Na}$ uptake in response to waterborne $\mathrm{Cu}(0.03-$ $5 \mu \mathrm{g} \mathrm{L}^{-1}$ ) at a specific external $\mathrm{Na}$ concentration can be 

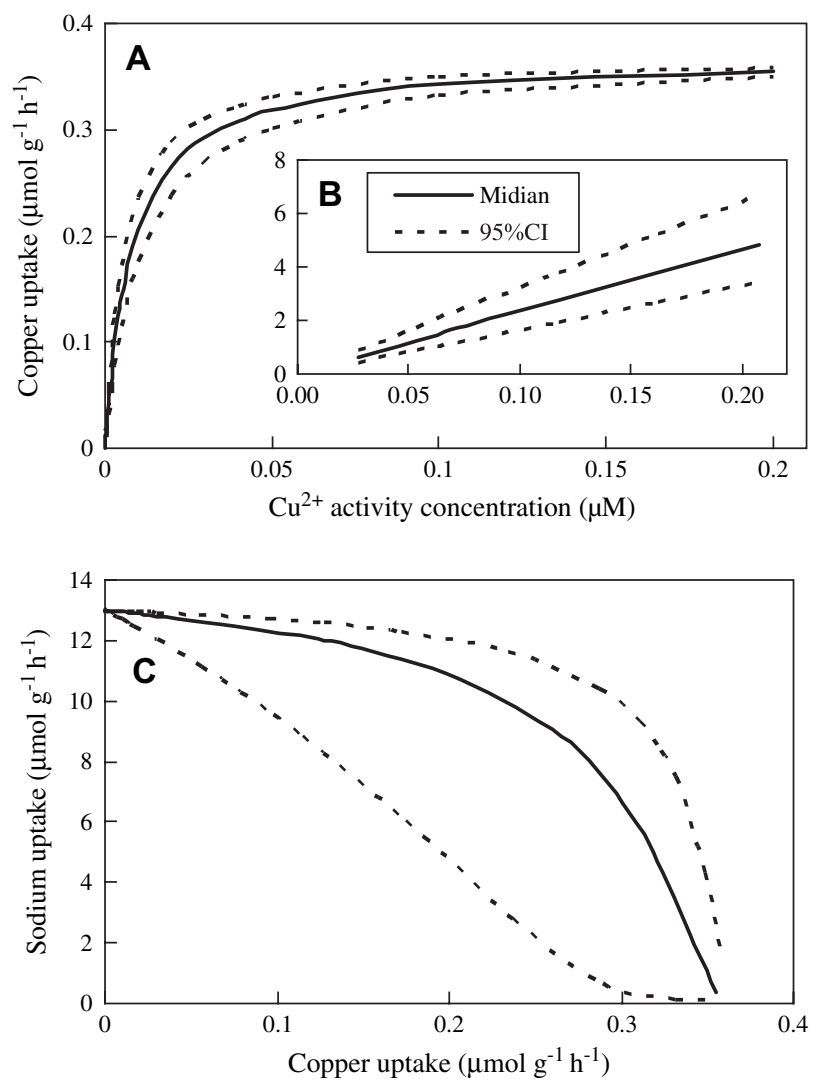

Fig. 8. Copper internalization flux in $C$. fluminea. (A) The $\mathrm{Cu}$ internalization flux profile as a $\mathrm{M}-\mathrm{M}$ kinetic model. (B) Diffusion-limited $\mathrm{Cu}$ internalization flux. (C) Predicted profile of the relationship between Na uptake and $\mathrm{Cu}$ internalization flux varied with different external $\mathrm{Cu}$ concentration.

predicted from Eqs. (14) and (15) for appropriate parameters where $\left.J_{\mathrm{Na}^{+}}(t, 0)\right|_{\mathrm{Na}^{+}}=J_{\max }=12.90 \mu \mathrm{mol} \mathrm{g}{ }^{-1}$ dry wt h ${ }^{-1}$ (Fig. 9). Fig. 9 implicates that our proposed models can not only quantitatively describe the Na-specific Na uptake dynamics along with the valve closure behavior when clams are exposed to waterborne $\mathrm{Cu}$ but can also be used as a tool to test the bivalve biological and physiological response abilities to close its shell as an alarm signal to reflect clam's health when they are exposed to $\mathrm{Cu}$.

\section{Discussion}

\subsection{Applications to biomonitoring protocols}

The use of novel biomonitoring strategy, including those exploiting simulation techniques, to better characterize aquatic ambient pollutant distributions and quantify source fluxes are required to understand and address the water quality problems they create. This is particularly true in the aquatic ecosystems, where the temporally and spatially undersampled data from conventional fixed water quality measurement sites is either limited or unavailable.

Continuous and rapid detection of environmental toxicity caused by waterborne metals is of great value for conserving aquatic ecosystems and protecting species health. Bivalves
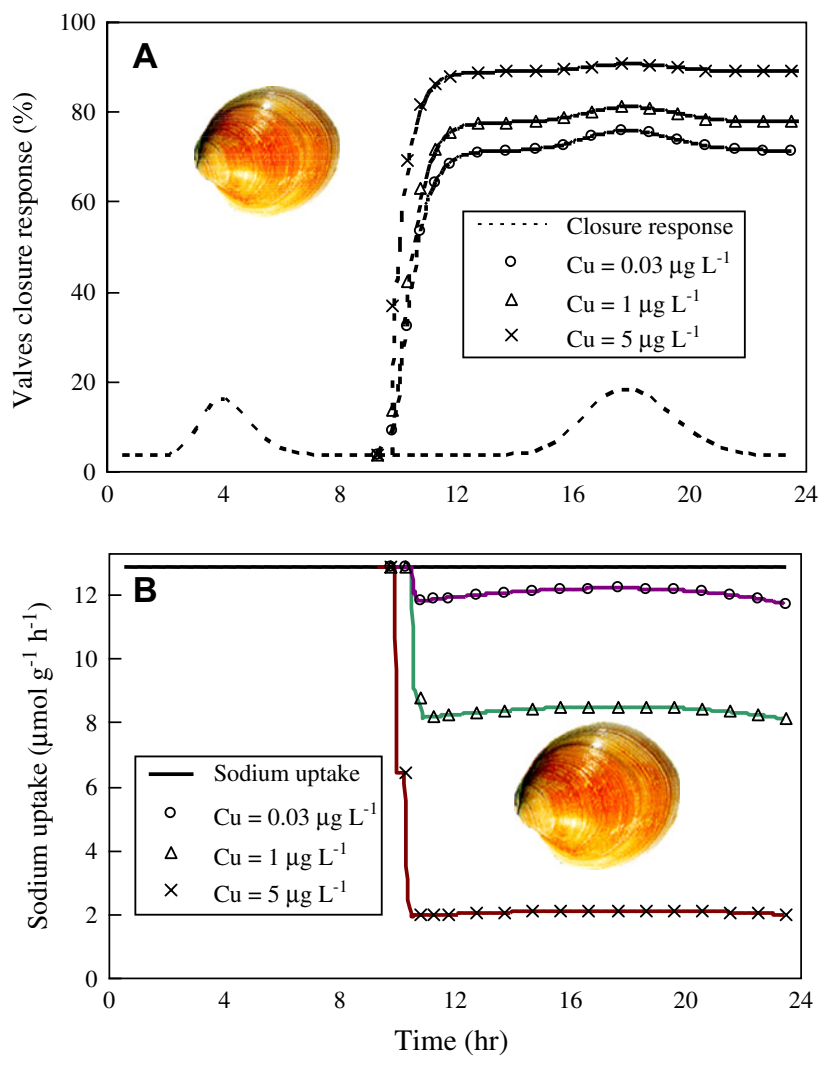

Fig. 9. Simulations of dynamic response of (A) clam valve closure behavior associated with (B) $\mathrm{Na}$ uptake rate in response to waterborne $\mathrm{Cu}$ of $0.03,1$, and $5 \mu \mathrm{g} \mathrm{L}^{-1}$ at 9:00 a.m. at a specific external Na concentration of $0.7 \mathrm{mM}$.

have been extensively used for monitoring environmental changes and the effect of these changes on the performance of aquatic organisms (Sloof et al., 1983; Doherty et al., 1987; Borcherding, 1994; Sluyts et al., 1996; Borcherding and Jantz, 1997; Curtis et al., 2000; Tran et al., 2003, 2004; El-Shenawy, 2004). Recent technological advances have allowed the development of robust, relatively compact, low cost, rapid response biomonitors with sufficient sensitivity and specificity to quantify many waterborne metals in the aquatic ecosystems.

Dynamic metal speciation analysis in aquatic ecosystems is emerging as a powerful basis for development of predictions of bioavailability and reliable risk assessment strategies (Kahru et al., 2005; van Leeuwen et al., 2005; Unsworth et al., 2006). Our Na uptake-valve closure dynamic analysis establishes the conditions under which complex chemical species will contribute to biouptake and furthermore to identify the domain of validity of BLM-based approach. The validity of our proposed concept has been established by application to published measurements of $\mathrm{Cu}$ biouptake fluxes in rainbow trout. Our proposed model therefore can be used to develop a dynamic biosensor to assess $\mathrm{Cu}$-uptake process and to measure $\mathrm{Cu}$ bioavailability based on the Na uptake-valve closure structure.

Since natural waters may contain trace metals (e.g., Zn, $\mathrm{Al}, \mathrm{Fe}$ ) other than $\mathrm{Cu}$ at appreciable concentrations, it is possible that these metals act to increase $\mathrm{Cu}$ bioavailability by competitive interactions with dissolved humic substances. 
Further investigation of these interactions is possible using the concept of our proposed model as the analytical tool to assess $\mathrm{Cu}$ bioavailability.

Therefore, our study, by integrating the $\mathrm{M}-\mathrm{M}$ rigorous flux analysis and BLM-based biological response to environmental chemical stressor, provides insight into the contribution of ion transport kinetics to bioavailability as sensed by freshwater organisms. Although assessment of $\mathrm{Cu}$ bioavailability in aquatic ecosystems remains difficult, the use of this $\mathrm{Cu}$-BLM-clam associated with Na uptake model is promising. Further development and simultaneous use of other dynamic sensors will further advance our understanding of $\mathrm{Cu}$ bioavailability to freshwater organisms.

\subsection{Applications to water quality criteria}

Ion transport associated with valve movement is a characteristic feature of $C$. fluminea and part of their natural behavior and it cannot be neglected as it is an important physiological factor for their survival (Zheng and Dietz, 1998; Tran et al., 2004). Transport of $\mathrm{Na}$ in C. fluminea is efficient and the affinity of the transport system for $\mathrm{Na}$ ions in these animals is greater than the affinity in the unionid mussels (McCorkle and Dietz, 1980). The $K_{\mathrm{m}}$ in $C$. fluminea is low relative to literature $K_{\mathrm{m}}$ values of $0.2-0.7 \mathrm{mM}$ in other freshwater animals and the exchange diffusion is characteristic of $\mathrm{Na}$ transport (McCorkle and Dietz, 1980). Changes in the valve movement rhythm and $\mathrm{Na}$ transport of $C$. fluminea can therefore be used as suitable endpoints in ecotoxicological risk assessment.

The $C$. flumenia are filter-feeder animals. They extend siphon from their bivalve shells to filter waterborne plankton or organic matter for uptake. Siphon extension is related to the magnitude of shell gape $(\%)$ that was proportioned to the valve position as well as percentage of the shell span (Ortmann and Grieshaber, 2003). When valve closure behavior in response to waterborne contaminants reduces $\mathrm{Na}$ uptake activity by closing their shells to escape toxicant damage and exclude themselves from the outside contaminated environment for maintaining their biotic faculty and increasing their survivability (Wildridge et al., 1998; Kadar et al., 2001).

Based on the valve position, we may use two different physiological responses with respect to behavioral activities of the clam as biological endpoints, i.e., valve closure and $\mathrm{Na}$ influx decreasing. Using different biological endpoints to develop BLM would be ideal for formulating predictive models of chronic low-level metal exposures in aquatic ecosystems. The present $\mathrm{Na}-\mathrm{Cu}-\mathrm{BLM}$-clam model offers a conceptual framework for integrating the influence of environmental factors such as water chemistry and bioavailability on biological response as monitored using valve movement behavior and $\mathrm{Na}$ uptake mechanism. We suggest that developing novel methods through BLM for interpreting biological response data will increase its utility in environmental risk assessment of toxicant exposure for aquatic species. Escher and Hermens (2004) pointed out that by linking bioavailability to effects could improve risk assessment and bridge the gap between human and environmental risk assessment.
Our $J(\phi)$ model has the ability to predict interplay relationships among valve closure response and internal $\mathrm{Na}$ level (Fig. 6B), inhibition of $\mathrm{Na}$ uptake and external $\mathrm{Cu}$ activity (Fig. 7B), and $\mathrm{Cu}$ internalization as a function of external $\mathrm{Cu}$ activity (Fig. 8A). By integrating Figs. 6B, 7B, and 8A, we can extend our model to a physiologically-based model of the survival time of $C$. fluminea exposed to $\mathrm{Cu}$ to provide a potential utility to longer-term ongoing efforts to develop and refine water quality criteria (WQC) (Paquin et al., 2002a,b; Grosell et al., 2002; Escher and Hermens, 2004). Meaningful WQC are needed to serve as a basis for development and implementation of a site-specific risk management strategy that will protect the aquatic environment, whereas at the same time result in the cost-effective implementation of control measures. From the perspective of the aquatic ecosystems, rather than developing a single-value waterborne metal concentration for establishing the WQC, it is better to derive a mechanistic model that explicitly incorporates the factors controlling bioavailability and bioaccumulation to enhance predictive ability to protect aquatic organisms.

Therefore, the present $J(\phi)$ model integrates knowledge of water chemistry with physiological transport mechanisms and biological response of organisms to generate a site-specific assessment of the toxicity of a given metal to the biota therein and provides a direct and quantitative method for evaluation of metal bioavailability in ecological risk assessment as a function of water chemistry and organism sensitivity to overcome frequently over-protective, and occasionally under-protective on site-specific WQC, thereby providing a means for estimating the effect of site-specific factors on metal toxicity.

\subsection{Implications}

Looking forward, we propose that this $\mathrm{Na}$ transport-valve behavior approach, which amounts to metal biodynamicstransport physiology-biological response of freshwater $C$. $f u$ minea within the BLM framework, might provide the basis of a future design of biomonitoring tool for measuring metal bioavailability to important freshwater species. Furthermore, this approach should have certain potential to provide a means to predict toxicity by influx rates for dissolved metals. A further inherent benefit of the $\mathrm{Na}$ transport-valve behavior approach is the identification of new bioindicators of dietary toxicity as a function of metal influx rates in the digestive tract that are predictive of individual responses.

The main potential application we envisage for $\mathrm{Na}$ transport-valve behavior approach is with respect to the health of freshwater clam to promote economic benefits on the development of bivalve extract that are now available on the market with a widely varying ornithine (Uchisawa et al., 2004). Wu and Shiau (2002) indicated that a freshwater clam extract or referred to as clam essence contained more ornithine than that in a chicken or beef essence. Recently, it has been reported that ornithine promotes the secretion of the growth hormone and builds muscle (Davenport et al., 1990; Bucci et al., 1990). Ornithine is thus attractive as an ingredient of dietary supplements. 
In principle, by using this methodology, metal-binding characteristics could be quantified upon exposures to waterborne $\mathrm{Cu}$, allowing evaluation of the relative contribution of the physiological mechanisms to the influx of metals. We envisage that optimal prediction of metal toxicity may eventually involve a variety of response-prediction approaches. However, by linking ion transport mechanism and BLM-based metal biodynamics to investigate clam biological response has an important theoretical advantage over traditional toxicity models (Luoma and Rainbow, 2005; Tsai and Liao, 2006) in that it can potentially take into account of both clam physiological and environmental factors affecting metal-induced biological responses. Furthermore, although our proposed model would normally relate to predicting xenobiotic-induced biological responses of freshwater species from influx rates, we envisage that similar methodology could also be applied to broaden the knowledge of the molecular and cellular mechanisms involved in the main physiological processes of interest including growth, reproduction, and immunity (Neumann and Galvez, 2002; Bricelj et al., 2005).

\section{References}

Bianchini, A., Bowles, K.C., Brauner, C.J., Gorsuch, J.W., Kramer, J.R., Wood, C.M., 2002. Evaluation of the effect of reactive sulfide on the acute toxicity of silver (I) to Daphnia magna. Part 2: toxicity results. Environmental Toxicology and Chemistry 21, 1294-1300.

Borcherding, J., 1994. The "Dreissena-Monitor" - improved evaluation of dynamic limits for the establishment of alarm-thresholds during toxicity tests and for continuous water control. In: Hill, I.R., Heimbach, F. (Eds.), Freshwater Field Tests for Hazard Assessment of Chemicals. Lewis Publishers, Boca Raton, FL, pp. 477-484.

Borcherding, J., Jantz, B., 1997. Valve movement response of the mussel Dreissena polymorpha - the influence of $\mathrm{pH}$ and turbidity on the acute toxicity of pentachlorophenol under laboratory and field conditions. Ecotoxicology $6,153-165$.

Bricelj, V.M., Connell, L., Konoki, K., Mac Quarrie, S.P., Scheuer, T., Catterall, W.A., Trainer, V.L., 2005. Sodium channel mutation leading to saxitoxin resistance in clams increases risk of PSP. Nature 434, 763-767.

Brown, P.L., Markich, S.J., 2000. Evaluation of the free ion activity model of metal-organism interaction: extension of the conceptual model. Aquatic Toxicology 51, 177-194.

Bucci, L., Hickson, J.F., Pivarnik, J.M., Wolinsky, I., McMahon, J.C., Turner, S.D., 1990. Ornithine ingestion and growth-hormone release in bodybuilders. Nutrition Research 10, 239-245.

Campbell, P.G.C., 1995. Interactions between trace metals and aquatic organisms: a critique of the free-ion activity model. In: Tessier, A., Turner, D.R. (Eds.), Metal Speciation and Bioavailability in Aquatic Systems. John Wiley \& Sons, Chichester, pp. 45-102.

Chen, B.C., Liao, C.M., 2004. Farmed tilapia Oreochromis mossambicus involved in transport and biouptake of arsenic in aquacultural ecosystems. Aquaculture 242, 365-380.

Croteau, M.N., Luoma, S.N., Topping, B.R., Lopez, C.B., 2004. Stable metal isotopes reveal copper accumulation and loss dynamics in the freshwater bivalve Corbicula. Environmental Science and Technology 38, 50025009.

Croteau, M.N., Luoma, S.N., 2005. Delineating copper accumulation pathways for the freshwater bivalve Corbicula using stable copper isotopes. Environmental Toxicology and Chemistry 24, 2871-2878.

Curtis, T.M., Williamson, R., Depledge, M.H., 2000. Simultaneous, long-term monitoring of valve and cardiac activity in the blue mussel Mytilus edulis exposed to copper. Marine Biology 136, 837-846.
Davenport, G.M., Boling, J.A., Schillo, K.K., Aaron, D.K., 1990. Nitrogenmetabolism and somatotropin secretion in lambs receiving arginine and ornithine via abomasal infusion. Journal of Animal Science 68, 222-232.

De Schamphelaere, K.A.C., Heijerick, D.G., Janssen, C.R., 2002. Refinement and field validation of a biotic ligand model predicting acute copper toxicity to Daphnia magna. Comparative Biochemistry and Physiology. Part C: Comparative Pharmacology and Toxicology 133, 243-258.

Dietz, T.H., Findley, A.M., 1980. Ion-stimulated ATPase activity and $\mathrm{NaCl}$ uptake in the gills of fresh-water mussels. Canadian Journal of ZoologyRevue Canadienne De Zoologie 58, 917-923.

Doherty, F.G., Cherry, D.S., Cairns, J.J., 1987. Valve closure responses of the Asiatic clam Corbicula fluminea exposed to cadmium and zinc. Hydrobiologia 153, 159-167.

El-Shenawy, N.S., 2004. Heavy-metal and microbial depuration of the clam Ruditapes decussates and its effect on bivalve behavior and physiology. Environmental Toxicology 19, 143-153.

Escher, I.E., Hermens, J.L.M., 2004. Internal exposure: linking bioavailability to effects. Environmental Science and Technology 38, 455A-462A.

Grosell, M., Nielsen, C., Bianchini, A., 2002. Sodium turnover rate determines sensitivity to acute copper and silver exposure in freshwater animals. Comparative Biochemistry and Physiology. Part C: Comparative Pharmacology and Toxicology 133, 287-303.

Hare, L., Tessier, A., 1996. Predicting animal cadmium concentrations in lakes. Nature 380, 430-432.

Jansen, S., Blust, R., van Leeuwen, H.P., 2002. Metal speciation dynamics and bioavailability: $\mathrm{Zn}(\mathrm{II})$ and $\mathrm{Cd}(\mathrm{II})$ uptake by mussel (Mytilus edulis) and Carp (Cyprinus carpio). Environmental Science and Technology 36, 2164-2170.

Kadar, E., Salanki, J., Jugdaohsingh, R., Powell, J.J., McCrohan, C.R., White, K.N., 2001. Avoidance responses to aluminium in the freshwater bivalve Anodonta cygnea. Aquatic Toxicology 55, 137-148.

Kahru, A., Ivask, A., Kasemets, K., Pollumaa, L., Kurvet, I., Francois, M., Dubourguier, H.C., 2005. Biotests and biosensors in ecotoxicological risk assessment of field soils polluted with zinc, lead, and cadmium. Environmental Toxicology and Chemistry 24, 2973-2982.

van Leeuwen, H.P., Town, R.M., Buffle, J., Cleven, R.F.M.J., Davison, W., Puy, J., van Riemsdijk, W.H., Sigg, L., 2005. Dynamic speciation analysis and bioavailability of metals in aquatic systems. Environmental Science and Technology 39, 8545-8556.

Liao, C.M., Jou, L.J., Chen, B.C., 2005. Risk-based approach to appraise valve closure in the clam Corbicula fluminea in response to waterborne metals. Environmental Pollution 135, 41-52.

Liao, C.M., Jou, L.J., Lin, C.M., Chiang, K.C., Chou, B.Y.H., Yeh, C.H. Predicting acute copper toxicity to valve closure behavior in the freshwater clam Corbicula fluminea supports the biotic ligand model. Environmental Toxicology, submitted for publication.

Luoma, S.N., Rainbow, P.S., 2005. Why is metal bioaccumulation so variable? Biodynamics as a unifying concept. Environmental Science and Technology 39, 1921-1931.

Markich, S.J., Brown, P.L., Jeffree, R.A., Lim, R.P., 2003. The effects of pH and dissolved organic carbon on the toxicity of cadmium and copper to a freshwater bivalve: further support for the extended free ion activity model. Archives of Environmental Contamination and Toxicology 45, 479-491.

Marr, J.C.A., Hansen, J.A., Meyer, J.S., Cacela, D., Podrabsky, T., Lipton, J., Bergman, H.L., 1998. Toxicity of cobalt and copper to rainbow trout: application of a mechanistic model for predicting survival. Aquatic Toxicology 43, 225-238.

Matsuo, A.Y.O., Playle, R.C., Val, A.L., Wood, C.M., 2004. Physiological action of dissolved organic matter in rainbow trout in the presence and absence of copper: sodium uptake kinetics and unidirectional flux rates in hard and softwater. Aquatic Toxicology 70, 63-81.

McCorkle, S., Dietz, T.H., 1980. Sodium-transport in the freshwater Asiatic clam Corbicula fluminea. Biological Bulletin 159, 325-336.

Morel, F.M.M., Hering, J.G., 1993. Reaction rates, rate constants and mechanisms: analysis of kinetic data. In: Morel, F.M.M., Hering, J.G. (Eds.), Principles and Applications of Aquatic Chemistry. Wiley, pp. $102-123$. 
Morgan, T.P., Wood, C.M., 2004. A relationship between gill silver accumulation and acute silver toxicity in the freshwater rainbow trout: support for the acute silver biotic ligand model. Environmental Toxicology and Chemistry $23,1261-1267$.

Neumann, N.F., Galvez, F., 2002. DNA microarrays and toxicogenomics: applications for ecotoxicology? Biotechnology Advances 20, 391-419.

Niyogi, S., Wood, C.M., 2004. Biotic ligand model, a flexible tool for developing site-specific water quality guidelines for metals. Environmental Science and Technology 38, 6177-6192.

Ortmann, C., Grieshaber, M.K., 2003. Energy metabolism and valve closure behaviour in the Asian clam Corbicula fluminea. Journal of Experimental Biology 206, 4167-4178.

Pagenkopf, G.K., 1983. Gill surface interaction model for trace-metal toxicity to fishes: role of complexation, $\mathrm{pH}$, and water hardness. Environmental Science and Technology 17, 342-347.

Paquin, P.R., Gorsuch, J.W., Apte, S., Batley, G.E., Bowles, K.C., Campbell, P.G.C., Delos, C.G., Di Toro, D.M., Dwyer, R.L., Galvez, F., Gensemer, R.W., Goss, G.G., Hogstrand, C., Janssen, C.R., McGeer, J.C., Naddy, R.B., Playle, R.C., Santore, R.C., Schneider, U., Stubblefield, W.A., Wood, C.M., Wu, K.B., 2002a. The biotic ligand model: a historical overview. Comparative Biochemistry and Physiology. Part C: Comparative Pharmacology and Toxicology 133, 3-35.

Paquin, P.R., Zoltay, V., Winfield, R.P., Wu, K.B., Mathew, R., Santore, R.C., Di Toro, D.M., 2002b. Extension of the biotic ligand model of acute toxicity to a physiologically-based model of the survival time of rainbow trout (Oncorhynchus mykiss) exposed to silver. Comparative Biochemistry and Physiology. Part C: Comparative Pharmacology and Toxicology 133, 305-343.

Saintsing, D.G., Towle, D.W., 1978. $\mathrm{Na}^{+}-\mathrm{K}^{+}$-ATPase in osmoregulating clam Rangia cuneata. Journal of Experimental Zoology 206, 435-442.

Sloof, W., De Zwart, D., Marquenie, J.M., 1983. Detection limits of a biological monitoring-system for chemical water-pollution based on mussel activity. Bulletin of Environmental Contamination and Toxicology 30, 400-405.

Sluyts, H., van Hoof, F., Cornet, A., Paulussen, J., 1996. A dynamic new alarm system for use in biological early warning systems. Environmental Toxicology and Chemistry 15, 1317-1323.
Tipping, E., 1994. WHAM-A computer equilibrium model and computer code for waters, sediments, and soils incorporating a discrete site/electrostatic model of ion-binding by humic substances. Computers and Geosciences 20, 973-1023.

Tran, D., Ciret, P., Ciutat, A., Durrieu, G., Massabuau, J.C., 2003. Estimation of potential and limits of bivalve closure response to detect contaminants: application to cadmium. Environmental Toxicology and Chemistry 22, 914-920.

Tran, D., Fournier, E., Durrieu, G., Massabuau, J.C., 2004. Copper detection in the Asiatic clam Corbicula fluminea: optimum valve closure response. Aquatic Toxicology 66, 333-343.

Tsai, J.W., Liao, C.M., 2006. A dose-based modeling approach for accumulation and toxicity of arsenic in tilapia Oreochromis mossambicus. Environmental Toxicology 21, 8-21.

Uchisawa, H., Sato, A., Ichita, J., Matsue, H., Ono, T., 2004. Influence of lowtemperature processing of the brackish-water bivalve, Corbicula japonica, on the ornithine content of its extract. Bioscience, Biotechnology and Biochemistry $68,1228-1234$.

Unsworth, E.R., Warnken, K.W., Zhang, H., Davison, W., Black, F., Buffle, J., Cao, J., Cleven, R., Galceran, J., Gunkel, P., Kalis, E., Kistler, D., van Leeuwen, H.P., Martin, M., Noel, S., Nur, Y., Odzak, N., Puy, J., van Riemsdijk, W., Sigg, L., Temminghoff, E., Tercier-Waeber, M.L., Toepperwien, S., Town, R.M., Weng, L.P., Xue, H.B., 2006. Model predictions of metal speciation in freshwaters compared to measurements by in situ techniques. Environmental Science and Technology 40, 1942-1949.

Wildridge, P.J., Werner, R.G., Doherty, F.G., Neuhauser, E.F., 1998. Acute effects of potassium on filtration rates of adult zebra mussels, Dreissena polymorpha. Journal of Great Lakes Research 24, 629-636.

Wu, H.C., Shiau, C.Y., 2002. Proximate composition, free amino acids and peptides contents in commercial chicken and other meat essences. Journal of Food and Drug Analysis 10, 170-177.

Zheng, H., Dietz, T.H., 1998. Ion transport in the freshwater bivalve Corbicula fluminea. Biological Bulletin 194, 161-169.

Zhou, B., Nichols, J., Playle, R.C., Wood, C.M., 2005. An in vitro biotic ligand model (BLM) for silver binding to cultured gill epithelia of freshwater rainbow trout (Oncorhynchus mykiss). Toxicology and Applied Pharmacology $202,25-37$. 